\title{
Integrated Intervention Program for Pregnant Women Toward ZIKA Virus Infection in Upper Egypt
}

\author{
Eman Ali Abd Elmoaty Sheha ${ }^{1}$, Hanan Elzeblawy Hassan², Eman Mohammed Mohammed Elsherbeny ${ }^{3}$ \& \\ Ahmed Abd-Elhakim Elgendy ${ }^{4}$ \\ ${ }^{1}$ Community Health Nursing Department, Faculty of Nursing, Fayoum University, Egypt \\ ${ }^{2}$ Maternal and Newborn Health Nursing, Faculty of Nursing, Beni-Suef University, Egypt \\ ${ }^{3}$ Community Health Nursing, Faculty of Nursing, Beni-Suef University, Egypt \\ ${ }^{4}$ Medical Physiology, Faculty of Medicine, Mansoura University, Egypt \\ Correspondence: Eman Ali Abd Elmoaty Sheha, Community Health Nursing Department, Faculty of Nursing, \\ Fayoum University, Egypt.
}

Received: September 7, 2020

Accepted: December 17, 2020

Online Published: March 15, 2021

doi:10.20849/ijsn.v6i1.870

URL: https://doi.org/10.20849/ijsn.v6i1.870

\begin{abstract}
Background: ZIKA infection may have long-term effects on reproductive health in addition to the neurological consequence in newborns. So, Awareness regarding ZIKA virus among pregnant women is important to take preventive measures. Aim: Evaluate the effect of integrated intervention guidelines on knowledge, self-reported practice of pregnant women toward ZIKA virus infection. Design: A quantitative quasi-experimental (pretest-posttest). Settings: The study was conducted at Obstetrics and gynecologic outpatient clinics at Fayoum University Hospital. Subjects: A convenient conducted among 240 pregnant women, assigned to 120 women in the control group, and 120 women in the study group. Two tools were used for data collection after reviewing relevant data; Tool $\boldsymbol{I}$ was a self-administered questionnaire to assess personal and obstetric characteristics of pregnant women, and their knowledge related ZIKA virus. Tool II was a self-reported practice questionnaire concerning self-protective measures regarding the prevention of ZIKA virus. Results: The results of this study showed that the majority of pregnant women was poor score level of knowledge and practice pre-intervention in both control and study group, however, there was an improvement of score level of knowledge and practice in the study group than control group post-intervention. Highly statistical significance was founded between control and study groups related to knowledge and practice. Positive significance correlation between pregnant women knowledge and practice score level post intervention in study group. Conclusion: The integrated intervention guideline improved pregnant women knowledge and practices. Recommendations: Continued efforts to close knowledge gaps, raise awareness and promote favorable attitudes toward ZIKA virus. Awareness about ZIKA virus infection should be ensured and maintained among all members of community, increased the prevention campaigns to improve community awareness of the seriousness of the disease, especially in rural areas.
\end{abstract}

Keywords: ZIKA virus, pregnant women, integrated intervention guideline

\section{Introduction}

The recent outbreak of ZIKA Virus Disease (ZVD) has become a major concern across the world concerns especially among pregnant women and women of reproductive age. [1] ZIKA virus is a Flavivirus that is mainly transmitted by Aedes aegypti and Aedes albopictus mosquitoes. [2] Globally, it is predicted that over 2.17 billion people live in areas that are environmentally suitable for ZIKA transmission, and 1.42 billion of them live in Asia. [3] In 2015, ZIKA positive cases have drastically surged in northeast Brazil and consequently a global epidemic was declared. There has been a rapid geographical expansion of the virus epidemic from 33 countries in early February 2016 [4] to 84 countries as of March 2018[5]. ZIKA-associated birth defects were identified in $6.0 \%$ of infants among pregnant women with completed pregnancies and laboratory evidence of ZIKA virus infection [6]. The World Health Organization (WHO) has recorded 2656 congenital syndromes associated with ZIKA virus infections in 31 countries, out of which 2653 (99.9\%) were in Brazil in March 2017 [7-8].

WHO (2016) declared that the observed increase of congenital microcephaly and other neurological disorders associated with the ZIKA outbreak constituted a public health emergency of both national and international 
concern. [9] ZIKA virus infection during pregnancy has been linked to stillbirths and to congenital ZIKA syndrome (CZS). While ZIKA virus infection in non-pregnant women has been linked to an increased incidence of Guillain-Barré syndrome. [10]

ZIKA virus infection tends to be either mild symptoms or asymptomatic, those who are symptomatic may include symptoms such as mild fever, skin rash, conjunctivitis, muscle, and joint pain, malaise, or headache. Despite being a mosquito-borne disease, ZIKA virus is also transmissible by various non-vector routes, including perinatal transmission, sexual transmission, and blood transfusion. [2, 11, 12] Additionally, the characteristics of ZIKA virus infection present new challenges for the public health response and long-term prevention. A large number of asymptomatic cases, the persistence of the virus in semen, and the preference of the mosquito for living within homes mean a higher risk of infection in low-income urban communities and particularly among vulnerable women and children. [13-15]

Hence, public health response is geared towards the prevention of infection mainly among pregnant women where one of its severe complications is microcephaly in babies born to infected mothers [1]. Diagnosis is by testing the blood, urine, or saliva for the presence of ZIKA virus RNA when the person is sick. [16] There is no effective vaccine and there is no specific treatment. Prevention involves decreasing the bites of mosquitoes in areas where the disease occurs and the proper use of preservatives. Efforts to prevent bites include using insect repellent, mosquito nets, covering much of the body with clothing, and getting rid of standing water where mosquitoes reproduce. [17]

Egypt's Health Ministry has already taken preventive action against ZIKA outbreak. According to Megáhed 2016, the Minister of Health's spokesperson, he stressed that the Ministry is working to secure two aspects: first, to secure all ports and airports by screening and moving people who might have come into touch with the virus into quarantine; second, check the mosquitoes and track the spread of the virus carefully. Such protective measures already existed in Egypt before the declaration of the state of emergency. [18] National surveys conducted in the United States in 2016 found that the degree of public awareness about ZIKA virus is small. [19, 20] Hence, women who are either currently pregnant or are planning to get pregnant must be aware about ZIKA virus infection and its potential consequences.

\subsection{Significant of the Study}

Prevention of ZIKA virus infection is becoming a major worldwide public health effort. The high-risk group for ZIKA virus infection comprises women who are pregnant or preparing for pregnancy. [21] Globally, the prevalence of antibody carriers is approximately 73.0\%. [22] More than 2000 neonates with microcephaly caused by ZIKA virus have been reported worldwide [23]. In addition, the number of newborns with congenital abnormalities that may affect learning, hearing, and vision, among other sequelae, has not been estimated yet. In Brazil, some women have decided not to get pregnant because of the impact that has been caused by the ZIKA virus [24].

This infection can be transmitted from an infected pregnant woman to her fetus or by sexual intercourse, which can lead to microcephaly a serious brain birth defect. [10, 25-27] Furthermore, ZIKA virus infection was designated as a communicable disease by law in 2016. [28] ZIKA virus infection has become a biological threat with severe burden effects on the well-being and quality of life of vulnerable groups both at micro and macro level. Hence, developing an understanding of a community's knowledge of ZIKA virus and practices toward preventive measures can be an important tool in designing future ZIKA interventions. Hence, maternity \& community health nurses play a crucial role in the quality of care improvement, which provides pregnant and puerperal woman education and support. At the same time, the nurse can provide health promotion \& psychosocial services include assessment, health education, and counseling \& appropriate referral. [29-35] Therefore, this study was done to evaluate the effect of an integrated intervention on pregnant women's knowledge and their practices.

\subsection{Aim of the Research}

The aim of the current study was to evaluate the effect of educational intervention guideline on knowledge, self-reported practice of pregnant women regarding ZIKA virus.

\subsection{Research Objectives}

1. Assess pregnant women's knowledge and self-reported practice regarding ZIKA virus before the implementation of the educational intervention.

2. Validate the designed an educational intervention guideline for pregnant women regarding ZIKA virus. 
3. Evaluate the effect of the educational intervention guideline on pregnant women's knowledge and self-reported practice regarding ZIKA virus.

\subsection{Research Hypothesis}

Educational intervention guideline will exhibit improvement in women's knowledge and self-reported practices regarding ZIKA virus.

\section{Subjects and Methods}

\subsection{Research Design}

A quantitative quasi-experimental (pretest-posttest) research design was utilized in the current study.

\subsection{Setting}

The study was conducted at Obstetrics and gynecologic outpatient clinics at Fayoum University Hospital.

\subsection{Subjects}

\subsubsection{Sample Type}

Convenient sample

\subsubsection{Sample Size}

A total of 240 pregnant women were recruited in the current study as the following (120) in the control group and (120) in the study group.

The sample size was calculated based on the previous 6 months census report of Fayoum University Hospital. The total number of pregnant women seeking care $=1200$ women (Fayoum University Hospital, Census, 2018). Sample size was calculated according to the following formula Yamane formula.

$$
n=\frac{N}{1+N(\mathrm{e}) 2}
$$

Where: $\mathrm{n}=$ sample size, $\mathrm{N}=$ total population number (500). $\mathrm{E}=$ margin error $(0.05)$.

\subsubsection{Recruitment Strategy}

Pregnant women admitted to the selected study setting at the time of data collection were directly asked to participate in the study after an explanation the purpose of the study. For the control group subjects, they were recruited from the period of the first month, and the study group subjects were recruited form the period of the second month.

\subsection{Tools of Data Collection}

Two tools were used for collecting data for the current study.

\subsubsection{First Tool}

A self-administered questionnaire; the study questionnaire was divided into two areas: 1) personal data, and obstetrical history such as (gravida, parity, and gestational age); 2) knowledge related ZIKA virus. This questionnaire area was developed following a review of the related literature. This questionnaire's area consisted of eleven closed-ended-questions, each question has a number of correct answers, these questions including definition of ZIKA virus, signs and symptoms of ZIKA virus, mode of transmission \& factors increase the risk for ZIKA virus, the effect of ZIKA virus on pregnant women and fetus and protective measures against ZIKA virus. The study subjects' answers were scored as (2) points for correct complete correct answer, (1) point for an incomplete answer, and (0) point of the wrong answer or don't know. The total knowledge score answers number was (22).

The total knowledge score was calculated as the following:

- Poor knowledge $<60 \%$ of total knowledge score (13 points)

- Fair knowledge $.60-75 \%$ of total knowledge score (14-17 points)

- Good knowledge $>75 \%$ of total knowledge score (>17 points)

\subsubsection{Second Tool}

A self-reported practice questionnaire concerning self-protective measures regarding the prevention of ZIKA virus was developed following literature review on the world health organization recommendations on the measures to prevent human-to-human transmission of ZIKA virus infection. This study questionnaire had (9) 
practice topics in order to reduce ZIKA virus infection among pregnant women. Each of these (9) practice had self-reported practice items, the study subjects were asked to select if they do practice rarely (done 1or 2 times per day), sometimes (done 2or 3 times per day) or usually (done more than 3 times per day). The self-reported practice questionnaire scored as the following (1) for rarely done, (2) for sometimes done, and (3) for usually done. The total self-reported practice score was (27).

The total self-reported practice score was calculated as the following:

- Unsatisfactory practice $<60 \%$ of total practice score (16 points)

- Satisfactory practice $.60-75 \% \%$ of total practice score (17-20 points)

- Highly satisfactory practice $>75 \%$ of total practice score (21-22 points)

\subsection{Content Validity}

The tools of data collection were submitted to a panel of 3 nursing experts in the field of obstetrics and gynecology and 3 nursing expertise in the field of community health and pandemic disease to test the content validity, modification was carried out according to the panel' judgments on the clarity of sentences and the appropriateness of the content. The result of the content validity index (CVI) delineated strongly accepting tools, it measured (0.83). In addition, the content of educational guidelines was reviewed by the panel of experts, and the guidelines' contents were reviewed critically from their original research papers and world health organization and they approved and validated its contents.

\subsection{Reliability}

The reliability was performed by Cronbach's Alpha test which showed that each of the two tools consisted of fairly homogenous items as shown by the moderate to the high reliability of each tool, it was $(0.86)$ for knowledge tool, and (0.91) for practice tool.

\subsection{Ethical Considerations}

Official permission was granted from directors of Fayoum University Hospital to facilitate data collection process. Written Informed consent was obtained from each woman before data collection and after explaining the purpose of the research. Anonymity was assured as the filled questionnaire sheets were given a code number. The researchers informed women that the information obtained will be confidential. The research maneuvers do not entail any risk effects on women. The women were informed about having the right to withdraw at any time without giving any reason.

\subsection{A Pilot Study}

The pilot study was carried out on 24 women. It is mainly established to test the simplicity, clarity, and applicability, ascertain the relevance and content validity of the tools, detect any problem unusual to the statements such as sequence and clarity that might interfere with the process of data collection as well as estimation of the time needed to fill the questionnaire. According to the results of the pilot study, the tools were clear and applicable, relevant, and valid; however, few words were modified and no problem interfered with the process of data collection. The estimated time needed to fill the questionnaire was 15 minutes. Following this pilot study, the tools were made ready for use. Women involved in the pilot excluded from the study to avoid contamination of the sample.

\subsection{Field Work}

Data of the current study was collected during a period of 3 months from the beginning of December 2019 and completed at the end of February 2020. The researcher visited the previously mentioned setting 3 days/week (Sunday, Monday, and Tuesday), from 9.00 am to $12.00 \mathrm{pm}$. To fulfill the aim of this research, the following phases were adopted, preparatory phase, interviewing and assessment phase, planning phase, implementation of the educational intervention phase, and evaluation phase.

\section{- A-Preparatory phase:}

The researchers conducted this phase by reviewing international related literature concerning the various aspects of the research problem. This phase helped the researchers to be familiar with the seriousness of the problem, and the researchers are directed by sample information help them to prepare adequately the required data collection tools.

\section{- B-Interviewing and assessment phase:}

In this phase, the researcher interviewed the women to collect baseline data. At the beginning of the interview, 
the researchers welcomed the participating women, explained the purpose of the research, and familiarized them with all information about the research (purpose, duration, and activities) and obtained their oral consent to participate in the research. A number of interviewed women per day ranged from (5-10) women. The data obtained during this phase were constituted the baseline for further comparison to evaluate the effect of the educational guideline.

\section{- C-Planning phase:}

Based on results obtained from both study and control group at the pretest during assessment phase, the educational guideline was developed by the researchers in a form of printed Arabic booklet to improve the studied women's deficit knowledge and self-reported practice regarding ZIKA virus. The designed educational guideline was provided for the women through 2 different theoretical sessions was done for a period of 30 minutes, and the researchers give attention that each woman follows precaution measures to avoid ZIKA virus infection. Objectives of the educational guidelines were constructed and included the following:

1. General Objectives aimed to equip the studied women with the essential required knowledge and self-practice concerning ZIKA virus infection.

2. Specific Objectives aimed to familiarize the studied women with abundant knowledge and self-care practice concerning ZIKA virus; its definition, signs and symptoms, characteristics, risk factors, preventive measures, etc....

\section{- D-Implementation of the educational intervention phase:}

Implementation of the educational intervention took 30 days and about 105 hours for all women recruited in the study group. The women were gathered in the waiting room of obstetrics and gynecology outpatient clinics at Fayoum University Hospital. Women in the study group received the educational intervention, the educational intervention was provided through two scheduled sessions. These sessions were repeated to each studied women. Each session took about 15-20 minutes. The researchers telephoned women to remind them of the follow-up appointment. At the end of each session, women's questions were discussed to correct any misunderstanding.

\section{- E- Evaluation phase:}

The effectiveness of educational intervention women's was evaluated one month after implementation using the same format of tools that used to evaluate knowledge and self-reported practice of both the study and the control group.

\subsection{Statistical Design}

Data analysis was performed using IBM SPSS statistical software version 22. The data were explored. Descriptive statistics were used for continuous variables (mean and standard deviation) and frequency for categorical variables. Qualitative variables were compared using qui square test $\left(\mathrm{X}^{2}\right)$ as the test of significance. The correlation coefficient (r) Pearson was used to evaluate the association between studied variables. A significant level value was considered when $\mathrm{p}$-value $\leq 0.05$.

\section{Results}

Table 1 illustrated that the mean age of women in the control and study group was $27.86 \pm 4.74$ years and 28.34 \pm 4.67 years old, respectively. The majority $(73.3 \% \& 70.0 \%)$ of the study subjects was lives in rural areas, slightly less than half of the studied subjects $(41.7 \%)$ had secondary education in the control group \& (37.5\%) had university education in the study group. Housewives presented $52.5 \%$ of the control group while $55.8 \%$ of the study group was employed, the most of them had enough monthly income $(62.5 \%$ \& $65.0 \%)$ and the majority live in extended family $(93.3 \%$ \& 92.5\%) in the control and study group, respectively. There was no statistically significant difference between control and study groups regarding personnel characteristics.

Table 2 reveals that slightly less than half of the studied subjects $(45.0 \%) \&(43.3 \%)$ were multigravida with three times, (48.2\%) (39.1\%) were multipara with two times and (44.2\%) (40.8\%) in the second trimester of pregnancy, $(55.0 \%) \&(50.8 \%)$ of them do antenatal follow up of their pregnancy in the control and study group respectively. There was no statistically significant difference between control and study groups regarding obstetric history.

As presented in Table 3, most of participants don't have knowledge related to ZIKA virus in all items pre-intervention in both control and study group, There was no statistically significant difference between control and study group in pre-intervention phase. However, the same table illustrated that the majority of participants in the study group showed complete correct answer in all knowledge items related to ZIKA virus at post-intervention phase while the minority of participants in the control group reported that they didn't know 
answer relevant to the same knowledge items post-intervention. There was a high statistically significant difference between the control and the study groups in post-intervention.

As presented in Table 4, most of the participants reported that they sometimes do practices toward ZIKA virus prevention in all items pre-intervention in both control and study groups, There was no statistically significant difference between control and study group in pre-intervention phase. However, the same table reveals that the most of participants in the study group showed they usually do practices toward ZIKA virus prevention in all items post-intervention compared to that the minority of participants in the control group showed rarely do practices relevant to the same practices items post-intervention. There was a high statistically significant difference between control and study group in post-intervention phase.

Figure 1 illustrated that the majority $(75.0 \% \& 70.1 \%)$ of participants had a poor score level of knowledge related to ZIKA virus pre-intervention in both control and study group. However, $73.3 \%$ of the studied subjects in the study group showed a good score level of knowledge post-intervention compared to $5.8 \%$ of the studied subjects in the control group.

Figure 2 illustrated that the majority of participants $(82.5 \% \& 84.2 \%)$ had unsatisfactory score level of practices related to ZIKA virus prevention pre-intervention in both control and study group, However, $75.0 \%$ of the studied subjects in the study group showed high satisfactory score level of practices post-intervention compared to only $8.3 \%$ of the studied subjects in the control group who showed high satisfactory score level of practices relevant to the same items post-intervention.

Table 5 showed positive correlation between participants' knowledge score level and practice score level pre and post-intervention in the control and study group. There was no statistically significant difference between participant knowledge and practices pre and post-intervention in control group. While there was a high statistically significant difference between participant knowledge and practices in the study group post-intervention.

Table 1. Distribution of personnel characteristics of the studied subjects $(n=240)$

\begin{tabular}{|c|c|c|c|c|c|c|}
\hline \multirow{2}{*}{$\begin{array}{l}\text { Personnel } \\
\text { characteristics }\end{array}$} & \multicolumn{2}{|c|}{ Control group } & \multicolumn{2}{|c|}{ Study group } & \multirow{2}{*}{$\begin{array}{l}\text { Chi } \\
\text { square }\end{array}$} & \multirow{2}{*}{$P$ value } \\
\hline & No & $\%$ & No & $\%$ & & \\
\hline \multicolumn{5}{|l|}{ Age in years } & \multirow{6}{*}{0.663} & \multirow{6}{*}{$>0.05$} \\
\hline $20-<25$ & 36 & $30.0 \%$ & 34 & $28.3 \%$ & & \\
\hline $25-<30$ & 35 & $29.2 \%$ & 32 & $26.7 \%$ & & \\
\hline $30-<35$ & 25 & $20.8 \%$ & 25 & $20.8 \%$ & & \\
\hline $35-40$ & 24 & $20.0 \%$ & 29 & $24.2 \%$ & & \\
\hline Mean $\pm S D$ & \multicolumn{2}{|c|}{$27.86 \pm 4.74$} & \multicolumn{2}{|c|}{$28.34 \pm 4.67$} & & \\
\hline \multicolumn{5}{|l|}{ Residence } & \multirow{3}{*}{0.328} & \multirow{3}{*}{$>0.05$} \\
\hline Rural & 88 & $73.3 \%$ & 84 & $70.0 \%$ & & \\
\hline Urban & 32 & $26.7 \%$ & 36 & $30.0 \%$ & & \\
\hline \multicolumn{5}{|l|}{ Educational level } & \multirow{5}{*}{2.30} & \multirow{5}{*}{$>0.05$} \\
\hline Read and write & 32 & $26.7 \%$ & 32 & $26.7 \%$ & & \\
\hline Secondary & 50 & $41.7 \%$ & 43 & $35.8 \%$ & & \\
\hline University & 37 & $30.8 \%$ & 45 & $37.5 \%$ & & \\
\hline Postgraduate & 1 & $0.8 \%$ & 0 & $0.0 \%$ & & \\
\hline \multicolumn{5}{|l|}{ Occupation } & \multirow{3}{*}{1.66} & \multirow{3}{*}{$>0.05$} \\
\hline Employed & 57 & $47.5 \%$ & 67 & $55.8 \%$ & & \\
\hline Housewife & 63 & $52.5 \%$ & 53 & $44.2 \%$ & & \\
\hline \multicolumn{5}{|l|}{ Monthly income } & \multirow{2}{*}{0.162} & \multirow{2}{*}{$>0.05$} \\
\hline Enough & 75 & $62.5 \%$ & 78 & $65.0 \%$ & & \\
\hline
\end{tabular}




\begin{tabular}{|c|c|c|c|c|c|c|}
\hline Not enough & 45 & $37.5 \%$ & 42 & $35.0 \%$ & & \\
\hline \multicolumn{5}{|c|}{ Type of family } & \multirow{3}{*}{0.063} & \multirow{3}{*}{$>0.05$} \\
\hline Nuclear & 8 & $6.7 \%$ & 9 & $7.5 \%$ & & \\
\hline Extended & 112 & $93.3 \%$ & 111 & $92.5 \%$ & & \\
\hline
\end{tabular}

$P>0.05$ Not Significant

Table 2. Distribution of obstetric history of the studied subjects $(n=240)$

\begin{tabular}{|c|c|c|c|c|c|c|}
\hline \multirow{2}{*}{ Obstetric history } & \multicolumn{2}{|c|}{ Control group } & \multicolumn{2}{|c|}{ Study group } & \multirow{2}{*}{$\begin{array}{l}\text { Chi } \\
\text { square }\end{array}$} & \multirow{2}{*}{ P value } \\
\hline & No & $\%$ & No & $\%$ & & \\
\hline \multicolumn{5}{|c|}{ Times of pregnancy } & \multirow{5}{*}{0.162} & \multirow{5}{*}{$>0.05$} \\
\hline Primigravida & 22 & $18.4 \%$ & 23 & $19.2 \%$ & & \\
\hline Gravida 2 & 31 & $25.8 \%$ & 33 & $27.5 \%$ & & \\
\hline Gravida 3 & 54 & $45.0 \%$ & 52 & $43.3 \%$ & & \\
\hline Gravida 4 & 13 & $10.8 \%$ & 12 & $10.0 \%$ & & \\
\hline \multicolumn{5}{|l|}{ Times of labor } & \multirow{5}{*}{3.12} & \multirow{5}{*}{$>0.05$} \\
\hline Nulliparous & 22 & $18.3 \%$ & 29 & $24.2 \%$ & & \\
\hline Para 1 & 37 & $30.8 \%$ & 38 & $31.7 \%$ & & \\
\hline Para2 & 58 & $48.2 \%$ & 47 & $39.1 \%$ & & \\
\hline Para 3 & 3 & $2.5 \%$ & 6 & $5.0 \%$ & & \\
\hline \multicolumn{5}{|l|}{ Gestational week } & \multirow{4}{*}{0.286} & \multirow{4}{*}{$>0.05$} \\
\hline First trimester & 39 & $32.5 \%$ & 42 & $35.0 \%$ & & \\
\hline Second trimester & 53 & $44.2 \%$ & 49 & $40.8 \%$ & & \\
\hline Third trimester & 28 & $23.3 \%$ & 29 & $24.2 \%$ & & \\
\hline \multicolumn{5}{|c|}{ Antenatal follow up } & \multirow{3}{*}{0.418} & \multirow{3}{*}{$>0.05$} \\
\hline Yes & 66 & $55.0 \%$ & 61 & $50.8 \%$ & & \\
\hline No & 54 & $45.0 \%$ & 59 & $49.2 \%$ & & \\
\hline
\end{tabular}

$\mathrm{P}>0.05$ Not Significant

Table 3. Distribution of ZIKA infection related knowledge among the studied subjects at the phase of pre-intervention and post-intervention $(n=240)$

\begin{tabular}{|c|c|c|c|c|c|c|c|c|c|c|c|c|c|c|c|}
\hline \multirow{3}{*}{ Variable } & \multirow{3}{*}{ phase } & \multicolumn{6}{|c|}{ Control group $(n=120)$} & \multicolumn{6}{|c|}{ Study group $(n=120)$} & \multirow{3}{*}{$\begin{array}{l}\text { Chi } \\
\text { square } \\
\text { test }\end{array}$} & \multirow{3}{*}{ P value } \\
\hline & & \multicolumn{2}{|c|}{ Don't know } & \multicolumn{2}{|c|}{ Incomplete } & \multicolumn{2}{|c|}{ Correct } & \multicolumn{2}{|c|}{ Don't know } & \multicolumn{2}{|c|}{ Correct } & \multicolumn{2}{|c|}{ Correct } & & \\
\hline & & No & $\%$ & No & $\%$ & No & $\%$ & No & $\%$ & No & $\%$ & No & $\%$ & & \\
\hline \multirow{2}{*}{$\begin{array}{l}\text { Definition of } \\
\text { ZIKA infection }\end{array}$} & Pre & 73 & $60.8 \%$ & 39 & $32.5 \%$ & 8 & $6.7 \%$ & 73 & $60.8 \%$ & 43 & $35.8 \%$ & 4 & $3.4 \%$ & 1.52 & $>0.05$ \\
\hline & Post & 73 & $60.8 \%$ & 39 & $32.5 \%$ & 8 & $6.7 \%$ & 11 & $9.2 \%$ & 11 & $9.2 \%$ & 98 & $81.6 \%$ & 137.85 & $<0.001 * *$ \\
\hline \multirow{2}{*}{$\begin{array}{l}\text { Causes of ZIKA } \\
\text { infection }\end{array}$} & Pre & 71 & $59.2 \%$ & 43 & $35.8 \%$ & 6 & $5.0 \%$ & 70 & $58.3 \%$ & 47 & $39.2 \%$ & 3 & $2.5 \%$ & 1.18 & $>0.05$ \\
\hline & Post & 66 & $55.0 \%$ & 48 & $40.0 \%$ & 6 & $5.0 \%$ & 13 & $10.8 \%$ & 26 & $21.7 \%$ & 81 & $67.5 \%$ & 106.75 & $<0.001 * *$ \\
\hline \multirow{2}{*}{$\begin{array}{l}\text { Signs/Symptoms } \\
\text { of ZIKA virus }\end{array}$} & Pre & 70 & $58.3 \%$ & 45 & $37.5 \%$ & 5 & $4.2 \%$ & 69 & $57.5 \%$ & 48 & $40.0 \%$ & 3 & $2.5 \%$ & 0.604 & $>0.05$ \\
\hline & Post & 62 & $51.7 \%$ & 53 & $44.2 \%$ & 5 & $4.3 \%$ & 18 & $15.0 \%$ & 18 & $15.0 \%$ & 84 & $70.0 \%$ & 111.57 & $<0.001 * *$ \\
\hline \multirow{2}{*}{$\begin{array}{l}\text { Vaccine of ZIKA } \\
\text { virus }\end{array}$} & Pre & 73 & $60.8 \%$ & 40 & $33.3 \%$ & 7 & $5.9 \%$ & 73 & $60.8 \%$ & 42 & $35.0 \%$ & 5 & $4.2 \%$ & 0.382 & $>0.05$ \\
\hline & Post & 65 & $54.2 \%$ & 48 & $40.0 \%$ & 7 & $5.8 \%$ & 12 & $10.0 \%$ & 33 & $27.5 \%$ & 75 & $62.5 \%$ & 5.649 & $<0.001 * *$ \\
\hline
\end{tabular}




\begin{tabular}{|c|c|c|c|c|c|c|c|c|c|c|c|c|c|c|c|}
\hline \multirow{2}{*}{$\begin{array}{l}\text { Treatment of } \\
\text { ZIKA virus }\end{array}$} & Pre & 66 & $55.0 \%$ & 43 & $35.8 \%$ & 11 & $9.2 \%$ & 62 & $51.7 \%$ & 47 & $39.2 \%$ & 11 & $9.2 \%$ & 0.303 & $>0.05$ \\
\hline & Post & 62 & $51.7 \%$ & 47 & $39.2 \%$ & 11 & $9.1 \%$ & 14 & $11.7 \%$ & 24 & $20.0 \%$ & 82 & $68.3 \%$ & 91.97 & $<0.001 * *$ \\
\hline \multirow{2}{*}{$\begin{array}{l}\text { Preventive } \\
\text { measures }\end{array}$} & Pre & 65 & $54.2 \%$ & 47 & $39.2 \%$ & 8 & $6.7 \%$ & 63 & $52.5 \%$ & 49 & $40.8 \%$ & 8 & $6.7 \%$ & 0.073 & $>0.05$ \\
\hline & Post & 60 & $50.0 \%$ & 52 & $43.3 \%$ & 8 & $6.7 \%$ & 13 & $10.8 \%$ & 28 & $23.3 \%$ & 79 & $65.9 \%$ & 95.40 & $<0.001 * *$ \\
\hline \multirow{2}{*}{$\begin{array}{l}\text { Risk factors of } \\
\text { ZIKA virus }\end{array}$} & Pre & 65 & $54.2 \%$ & 47 & $39.2 \%$ & 8 & $6.7 \%$ & 61 & $50.8 \%$ & 51 & $42.5 \%$ & 8 & $6.7 \%$ & 0.290 & $>0.05$ \\
\hline & Post & 60 & $50.0 \%$ & 52 & $43.3 \%$ & 8 & $6.7 \%$ & 9 & $7.5 \%$ & 26 & $21.7 \%$ & 85 & $70.8 \%$ & 110.11 & $<0.001 * *$ \\
\hline \multirow{2}{*}{$\begin{array}{l}\text { Complication of } \\
\text { ZIKA virus }\end{array}$} & Pre & 63 & $52.5 \%$ & 46 & $38.3 \%$ & 11 & $9.2 \%$ & 61 & $50.8 \%$ & 48 & $40.0 \%$ & 11 & $9.2 \%$ & 0.075 & $>0.05$ \\
\hline & Post & 58 & $48.3 \%$ & 51 & $42.5 \%$ & 11 & $9.2 \%$ & 7 & $5.8 \%$ & 42 & $35.0 \%$ & 71 & $59.2 \%$ & 84.78 & $<0.001 * *$ \\
\hline \multirow{2}{*}{$\begin{array}{l}\text { Effect of ZIKA } \\
\text { on pregnancy }\end{array}$} & Pre & 64 & $53.3 \%$ & 45 & $37.5 \%$ & 11 & $9.2 \%$ & 60 & $50.0 \%$ & 49 & $40.8 \%$ & 11 & $9.2 \%$ & 0.299 & $>0.05$ \\
\hline & Post & 60 & $50.0 \%$ & 49 & $40.8 \%$ & 11 & $9.2 \%$ & 11 & $9.2 \%$ & 24 & $20.0 \%$ & 85 & $70.8 \%$ & 99.42 & $<0.001 * *$ \\
\hline \multirow{2}{*}{$\begin{array}{l}\text { Effect of ZIKA } \\
\text { virus on fetus }\end{array}$} & Pre & 69 & $57.5 \%$ & 40 & $33.3 \%$ & 11 & $9.2 \%$ & 63 & $52.5 \%$ & 49 & $40.8 \%$ & 8 & $6.7 \%$ & 1.65 & $>0.05$ \\
\hline & Post & 62 & $51.6 \%$ & 47 & $39.2 \%$ & 11 & $9.2 \%$ & 7 & $5.8 \%$ & 42 & $35.0 \%$ & 71 & $59.2 \%$ & 88.02 & $<0.001 * *$ \\
\hline \multirow{2}{*}{$\begin{array}{l}\text { Precaution when } \\
\text { using pesticides }\end{array}$} & Pre & 64 & $53.3 \%$ & 42 & $35.0 \%$ & 14 & $11.7 \%$ & 59 & $49.2 \%$ & 50 & $41.7 \%$ & 11 & $9.2 \%$ & 1.25 & $>0.05$ \\
\hline & Post & 54 & $45.0 \%$ & 52 & $43.3 \%$ & 14 & $11.7 \%$ & 11 & $9.2 \%$ & 24 & $20.0 \%$ & 85 & $70.8 \%$ & 89.68 & $<0.001 * *$ \\
\hline
\end{tabular}

$\mathrm{P}>0.05$ Not Significant

$* * \mathrm{P} \leq 0.001$ High Significance

Table 4. Distribution of ZIKA infection prevention related practice among the studied subjects at the phase of pre-intervention and of post-intervention $(n=240)$

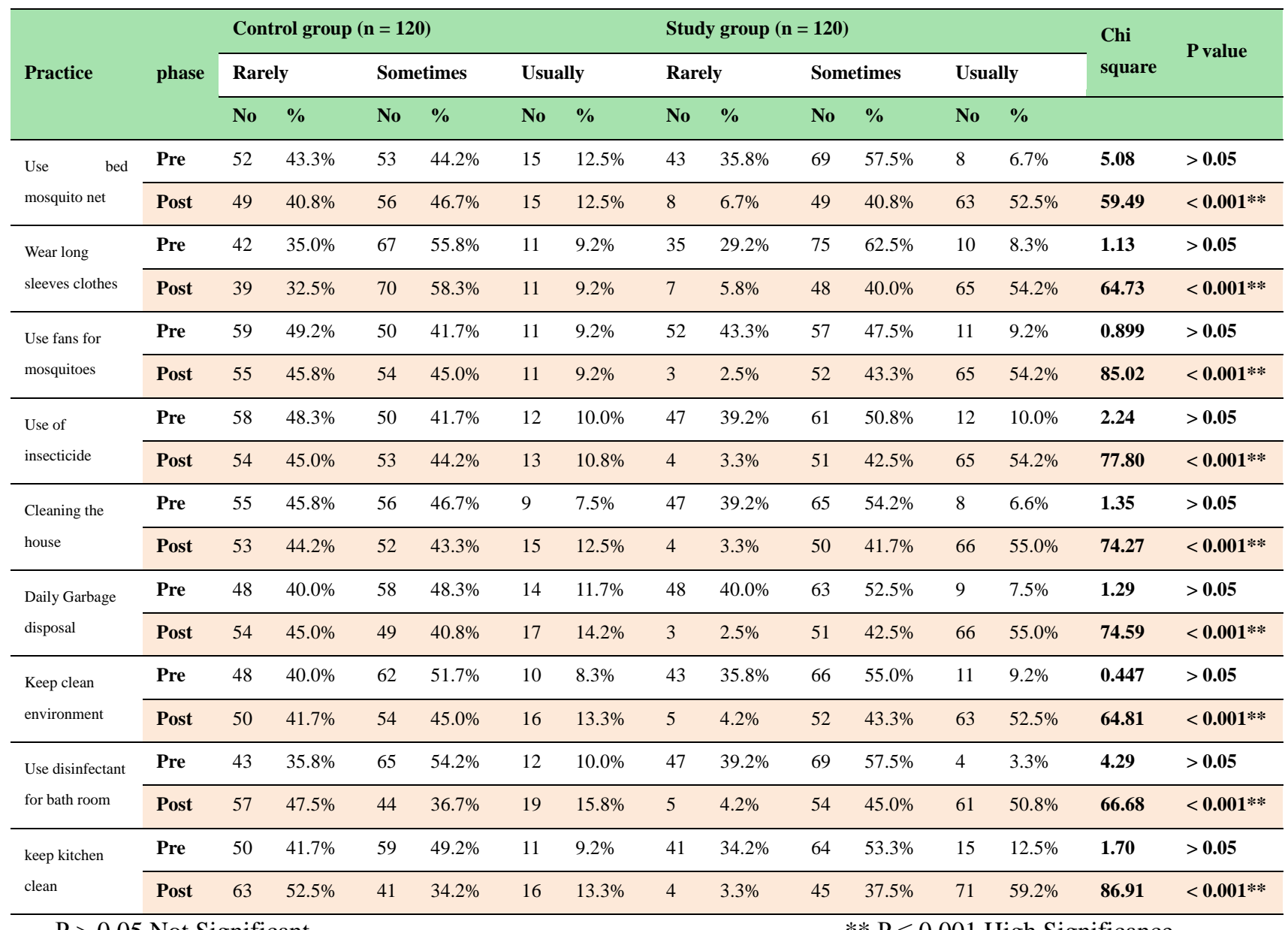




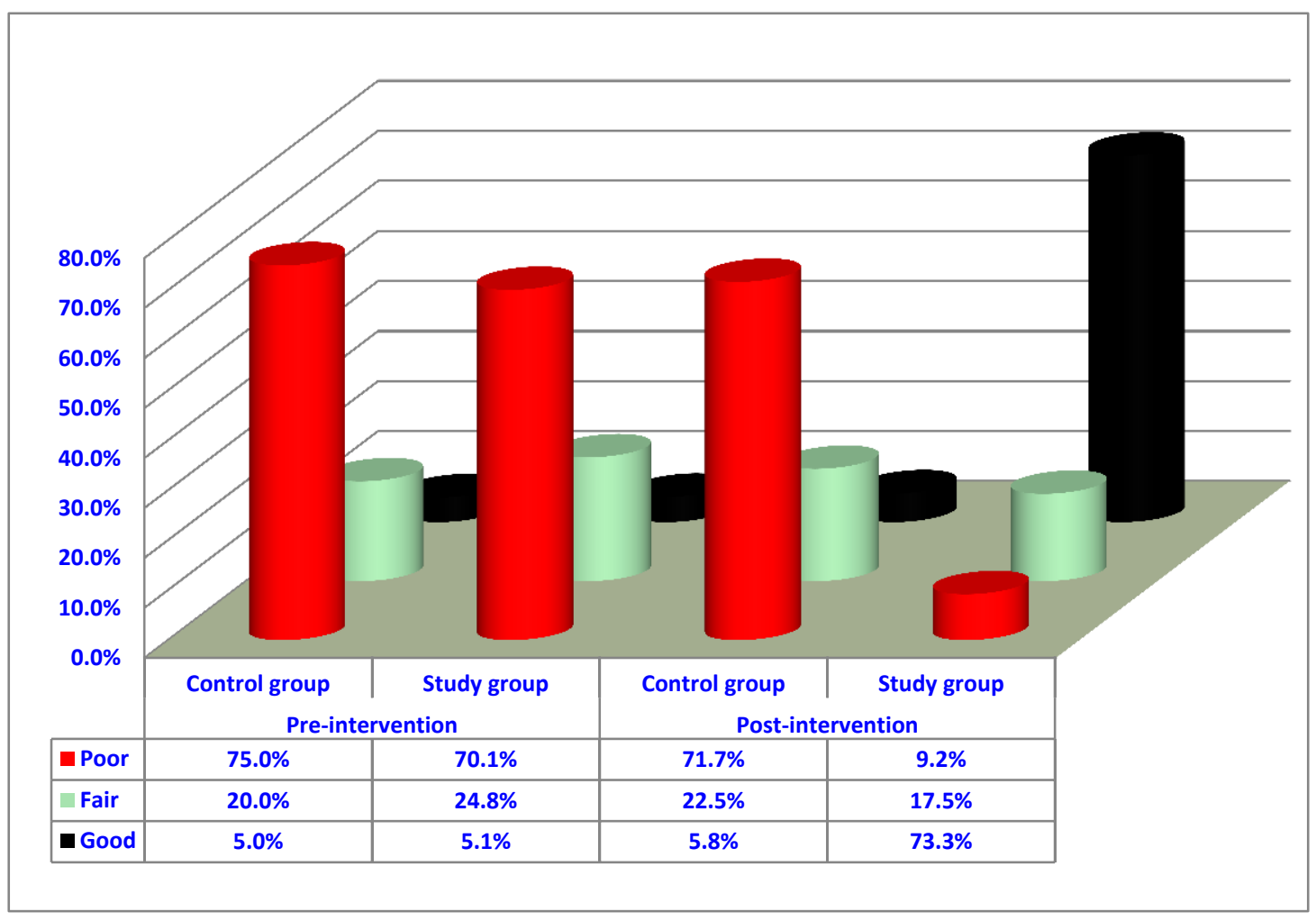

Figure 1. Percentage distribution of total ZIKA infection knowledge score of the studied subjects at both pre \& post intervention phases

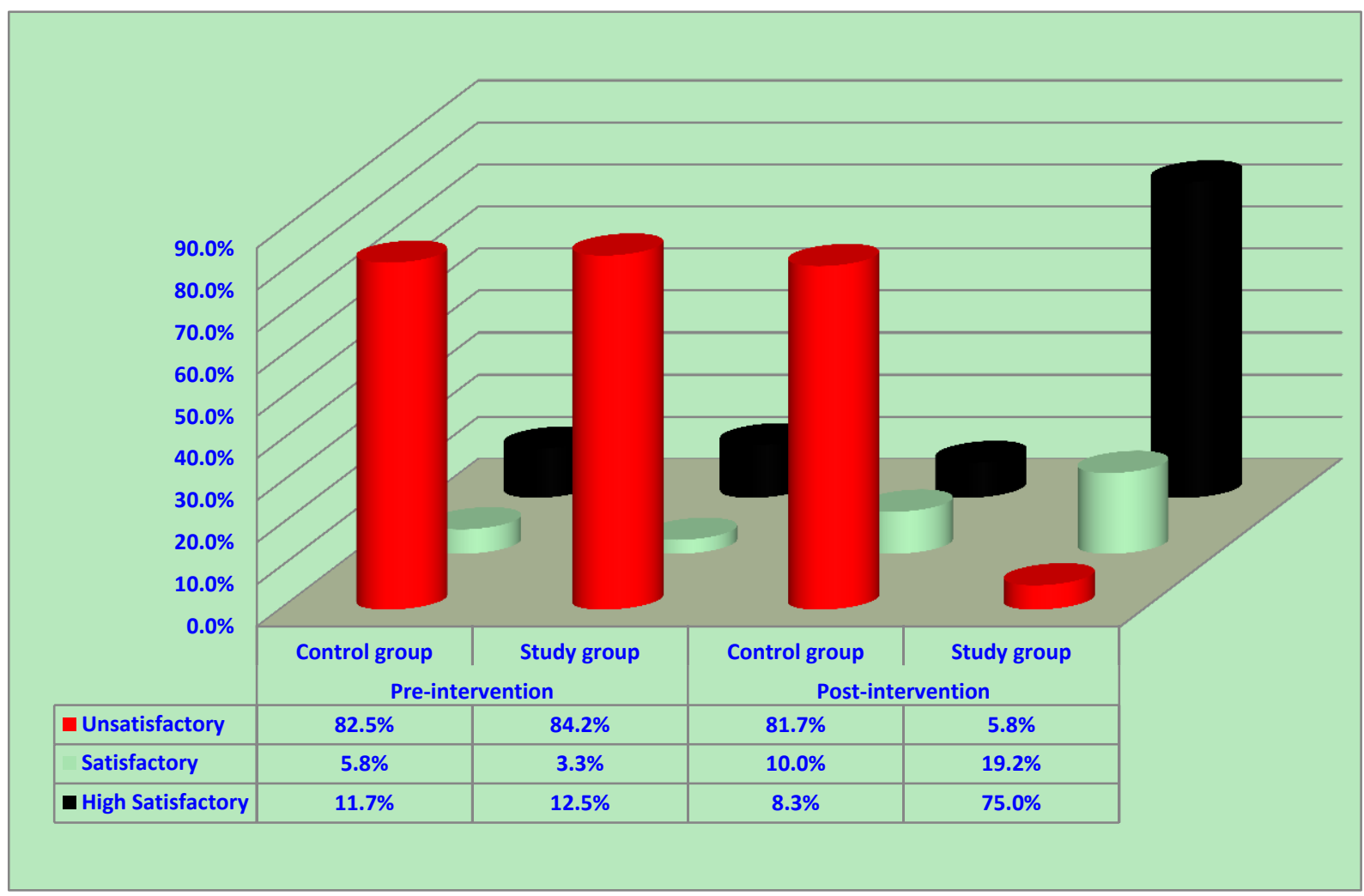

Figure 2. Percentage distribution of total ZIKA infection prevention practice score of the studied subjects at both pre \& post intervention phases 
Table 5. Correlation between Study subjects' knowledge and practices toward ZIKA infection in Control and Study Groups at both Pre \& Post intervention phases

\begin{tabular}{lllll}
\hline \multirow{2}{*}{ Variables } & \multicolumn{2}{l}{ Practice Score Level } \\
\cline { 2 - 5 } & \multicolumn{2}{l}{ Control group } & \multicolumn{2}{l}{ Study group } \\
\cline { 2 - 5 } & $\mathrm{r}$ & P value & $\mathrm{r}$ & P value \\
\hline Knowledge Score Level & & & & \\
\hline Pre Intervention & 0.132 & $>0.05$ & 0.163 & $>0.05$ \\
\hline Post Intervention & 0.143 & $>0.05$ & 0.356 & $<0.001^{* *}$ \\
\hline
\end{tabular}

\section{Discussion}

Effective strategies are encouraged for the prevention and control of the virus, such as mosquito vector control and community education. The community and Maternity health nurse had an important role in primary prevention, health protection, health promotion, health education, and health surveillance to identify, prevent, protect, and manage ZIKA virus infection. Nurses have the responsibility to keep currency with the evolving body of knowledge about the infection in order to provide optimal patient care. [36]

Concerning to personnel characteristics of the studied women, the present study revealed that the mean age of women who participated in the study was $27.86 \pm 4.74$ years and $28.34 \pm 4.67$ years old in control and study group, respectively. The highest proportion belongs to the 20-25 age group followed by 25-30 age groups in both groups. All studied subjects were female. The majority of the studied women in both groups were lives in rural areas, around half of them had secondary education in the control group \& university education in the study group, housewives in the control group \& employed in the study group, while the majority of them had enough monthly income and live in an extended family in both group. It was clear that there was no statistically significant difference between control and study groups regarding personnel characteristics which indicated homogeneity of groups. Moreover, this suggests that most of the pregnant women are close in personal characteristics and are reflected on them the rural character that makes pregnancy at a young age, makes the majority of families living together in an extended family.

These results were in accordance with a finding of Zahra et al., (2018) that reported the mean age of pregnant women was $27.58 \pm 8.26$ years, slightly less than two-thirds of them are employed, reside in a rural area. Most of them had secondary education. [37] Results of the current study were in consistence with the findings of previous studies that reported most of the participant was female, with average age 21.9 years, however, highest proportion belongs to the 25-34 years. [38-40] In the same line, the results agreed with the finding showed that the majority of study subjects are females, belongs to low family income and $55.6 \%$ are in the age group of $18-19$ years, $38.9 \%$ are in the age group of $20-21$ years and 5.6\% are in the age group of 21 and above, however, the most of them from urban area and only one third of them from rural area. [41]

Also, these findings were consistent with the results of a study that reported the median age of pregnant women respondents was 27 years, and 37.9\% of pregnant respondents were high school graduates. [42] Another study reported that more than two-thirds of the study sample had a secondary level of nursing education. [43] Similarly, another study concluded that the most of studied sample were female with a mean age of 33.6 years old. The majority was a middle economic level and 50.3\% were employed.[21] Additionally, research by Chaw L. et al 2018 showed that the median age of the studied sample was 28.0 years, a large proportion lived in households with extended 5 to 8 members; but $32.1 \%$ reported a monthly household low income, while $43.2 \%$ reported average income. [44]

According to obstetric history of the studied subjects, around half of them in both groups were multigravida three times, multiparous with two times, in the second trimester of pregnancy, and do antenatal follow up of their pregnancy. There was no statistically significant difference between control and study groups regarding obstetric history. Perhaps this is due to the most of pregnant women participating in the study in the second and third stages of pregnancy are due to the culture of the mothers who grew up on it, especially in Upper Egypt, where women in the first stage of pregnancy do not go to follow up their pregnancy for fear of causing abnormalities in the fetus and are satisfied with first signs of pregnancy and after the first stage of pregnancy passes you go to follow up her pregnancy.

These results were in accordance with a finding that reported a large percent of participants in the second 
trimester followed by third trimester. [45] Moreover, This was supported by the findings of other studies that concluded the most of the women were in their second or third trimester of pregnancy. [42, 46]

The results of the current study reveal that the most of participant don't have knowledge related to ZIKA virus infection in all items as definition, causes, signs, and symptoms, vaccine, treatment, preventive measures, risk factors, complication, its effect on pregnant women and fetus and precaution when using pesticides in both groups' prior interventions. However, the majority of studied women in the study group answered complete correct answers post-intervention relevant to the same mentioned items. It was clear that there was no statistically significant difference between control and study group pre-intervention. The explanation of this poor knowledge is ZIKA infection is a new emerging infectious disease. Although the virus was announced by the media, perhaps community members, especially pregnant women, were not interested in knowing this because they believed that the disease in other countries was too far away and could not come to our country.

These results suggest the need for pregnant women education to promote knowledge about ZIKA virus. This was supported by the findings that concluded the lack of knowledge on ZIKA virus infection among pregnant women attending government maternal and child healthcare centers in Brunei Darussalam. [44] Additionally, these results were in accordance with a finding that reported an improvement in knowledge of the pregnant women post-program. There are highly statistical differences regarding women's' knowledge about ZIKA virus pre and post-intervention was observed. [37] This point of view was consistent with the results of a study that increased knowledge awareness of patients post-handout $(\mathrm{p}<0.05)$ regarding transmission, fetal risks, signs and symptoms, prevention, and travel warnings. [47]

Similarly, another study declares that pregnant women need more education on the ZIKA virus disease and assurance regarding the safety of using repellent during pregnancy. [46] In the same line the results agreed with the finding of other studies. [48-52] The results of the present study are in consistence with a study that showed the majority of the participants hadn't the correct knowledge about mode of transmission; clinical picture, duration of disease, and its effect on pregnancy outcome, complication, precautions are taken and prophylactic measures with highlight knowledge gaps. [43] In the same line, the results agreed with the finding showed that the majority of the respondents have an inadequate knowledge about ZIKV and improved by intensifying the annual awareness-raising Hajj campaigns that are conducted in the hospitals. [40] These finding also come in agreement with the study of Shartzer A. 2016 who found that there was knowledge gap of women in reproductive age about ZIKA virus. [53]

In addition, previous research surveyed practitioners from different countries showed that the majority of participants had inadequate knowledge of the ZIKA virus. [49, 54] However, these previous findings were in contrast to the findings of another recent study conducted among GPs in Indonesia showed that the majority of them had a good knowledge of pregnancy-related issues of ZIKA virus. [55-56] On the contrary Ricamonte B. et al 2018 reported that the majority $(91.2 \%)$ of pregnant women knew the main source of mosquitoes that causes ZVD. Likewise, many were knowledgeable about the preventive measures $(87.3 \%)$ and the most common symptoms of the disease ( 74.5 per cent) can not only be acquired by females (53.9 per cent); cleaning the atmosphere can avoid ZVD spread (54.9 per cent). On the other hand, less than half knew the disease transmissions' way. [57]

In contrast to this study, good knowledge of ZIKA virus was reported of several studies conducted in Malaysia. [58-60] Also, Singh M 2017 revealed that all the participants had adequate knowledge on the topic of ZIKA. [61] possibly the difference in information about the disease is due to the medical staff, by the nature of his work, is more exposed to such diseases, so it is natural for them to know more than ordinary people. Also, perhaps more information is available to people in other countries as a result of living in the areas most vulnerable to the disease.

The results of the present study conveying and confirming a similar poor score level of knowledge in both groups' prior interventions, however, improvement of the women knowledge that showed a total good score level among the study group compared to control group that showed poor score level of knowledge post-intervention. It was clear that there was a high statistically significant difference between control and study group in post-intervention. Perhaps after the researcher applied the integrated intervention program, pregnant women became aware of the seriousness of the disease, especially for the fetus, so they received information with interest because they feared for herself and her fetus, so their information about the virus actually improved.

This improvement could be getting as a result of educational methods variety that the researcher used and the Arabic book gotten to each woman. Too much reliance on the distribution of written materials in the form of booklets is placed in many educational programs. They can remind women of the topics they've learned in other 
ways. Booklets are better used when they're short, full of good pictures and used to back up certain educational types. [62-65] This is in accordance with the Pyramid of Learning cited by Masters K as by Edgar Dale or by the NTL; as many authors cited. [66-69] The pyramid showed that people can retain 10\% of what they read, and $20 \%$ of what they see and understand (audiovisual). The same authors added that some would retain $50 \%$ of what he learned through discussion. [70]

This view was in accordance with the findings showed that $59.8 \%$ of pregnant women had a low level of knowledge about ZIKA virus. [57] This finding is supported by the results showed that $72.5 \%$ of them had poor knowledge scores. [43] In the same line, the results agreed with the finding showed that $72.4 \%$ of participants had poor score knowledge pre-intervention and $50.5 \%$ of participants had good score knowledge post-intervention. [37] These findings are consistent with the study of Harapan H. 2017 in which the studied sample had poor knowledge about ZIKA virus. [48] In contrast to this study had observed a good knowledge score level regarding the Ebola virus disease during its outbreak in their study. [71] Nevertheless, a study among dental practitioners conducted in Tricity presented a similar finding. [72]

This result conveying and confirming the most of participant sometimes done practices toward ZIKA virus prevention in all items as use bed mosquito net, wear long sleeves clothes, use of fans to expel mosquitoes, use of insecticide for mosquito, cleaning the house, daily garbage disposal, keep the environment surrounding house clean, usually keep bathroom clean with disinfectant solutions and usually keep the kitchen clean in both group prior intervention. There was no statistically significant difference between control and study group pre-intervention. However, post-intervention, the results showed that the women who participated in the study group usually done practices with significantly higher improved their practices in all items regarding ZIKA virus prevention compared to the women in the control group relevant to the same items. Suggesting that this improvement related to the pregnant women interacted with the program and obtained correct and repeated training from the researcher due to their eagerness to prevent infection.

To confirm that pregnant women needed this, Cheema et al. 2017 \& Huang et al. 2017 reported that ZIKA virus infection requires prevention campaigns focused on pregnant women, women preparing for pregnancy, and their partners. $[54,73]$ The results of the present study were in accordance with the results that proved; there was an improvement in pregnant women practice post-program, there is a highly statistical difference regarding pregnant women practices pre and post-intervention. [37]

In accordance with Taís \& David 2017 who found that $51.8 \%$ claimed to always do some prevention measures in their daily life basis. [74] This finding is supported by the results of Heitzinger (2018) who conducted a survey about Knowledge, Attitudes, and Practices of Women of Childbearing about ZIKA Virus in Kentucky and showed that two-thirds of the participants reported taking action to prevent ZIKA infection while traveling or living in a ZIKA-affected area; (53\%) of them use of mosquito repellent, followed by (18\%) of them wearing protective clothing. [75] In the same line, the results agreed with the finding showed that less than $3 \%$ of pregnant women mentioned hearing about individual actions that could be taken to prevent ZIKA virus infection. [42]

It was clear that a similar poor score level of practices in both groups prior interventions. However, the majority of the studied women in the study group showed a high satisfactory total score level of practice rather than the control group post-intervention. There was a high statistically significant difference between control and study group post-intervention. These findings were consistent with the results of a study that concluded $(75.2 \%)$ of pregnant women had unsatisfactory practice pre-intervention compared to $79 \%$ of pregnant women had satisfactory practice post-intervention. [37] Similarly, this was supported by other studies have shown that health personnel in ZIKA endemic areas have a low level of preventive practices related to ZIKA virus prevention. [76-77] Also, another study declared that insufficient participants practices in ZIKA prevention. [45] In the same line the results agreed with the finding showed all categories of healthcare providers showed a low level of knowledge and practices in pre-program as compared to post-program. [78]

The result of the present study showed a positive correlation between pregnant women's knowledge score level and practice score level pre and post-intervention in the control group (pre $r=0.132$, post $r=0.143$ ). There was no statistically significant difference between participant knowledge and practices pre and post-intervention in the control group $(\mathrm{P}>0.05)$. Also, the result of the current study reveal a positive correlation between pregnant women's knowledge score level and practice score level pre and post-intervention in the study group (pre $\mathrm{r}=$ 0.163 , post $r=0.356$ ). There was a high statistically significant difference between participant knowledge and their practices in the study group $(\mathrm{P} \leq 0.001)$ post-intervention. This may have due to the provision of more knowledge that will improve their practices. Moreover, increased pregnant women's knowledge is a strong 
predictor for increased their practices toward ZIKA virus prevention.

The results of the conducted study were in accordance with the results that proved there was a positive linear relation was found pre and post-intervention between knowledge and practices of participants. [78] In accordance with the finding reported that pregnant women's knowledge and practice were significantly related. [79] This was supported by Yap J. et al. 2010 who reported that a higher knowledge score was found to be a strong predictor of higher practice scores among military servicemen about swine flu in Singapore. [80] In the same line, the results agreed with the finding showed that there was a linear correlation between studied sample knowledge and practice scores with regard to infection prevention and control. $(\mathrm{r}=0.146, \mathrm{p}<0.05)$. [81] Moreover, another study concluded that there was a significant positive correlation between pregnant women's knowledge regarding hepatitis B and practice towards its prevention. [82]

These results were in accordance with a finding that indicates a moderately strong positive linear relationship between participants' knowledge and practice. However, good knowledge is crucial for ensuring expected levels of infection control practices and hence ensures patient safety. [83] Similarly, some studies concluded that there are highly statistically significant differences between the knowledge of studied sample and their practices, most of the participants in the study group who sufficient knowledge had proper practices after implementation of an educational program. [84, 65] However, these previous findings were in contrast to the findings of another study concluded an insignificant correlation between total score knowledge and practice pre and post-intervention. [37] Similarly, There was a weak negative correlation between the overall percent of participant knowledge score and overall percent practice was reported by Iliyasu G. et al. 2016. [85] Argüelles-Nava V. et al. 2018 emphasized that the correlation between knowledge and practices show a discrepancy, suggesting that although people have knowledge about the risk of ZIKA infection, proper preventive measures are not taken $(\mathrm{p}<0.001)$. [86]

In contrast to this study, Nelson E. 2018 observed that the sexual prevention methods were more likely to be used by individuals who reported having knowledge of the sexual transmissibility of ZIKA than those who did not have this knowledge. [87] Our findings are similar to other ZIKA KAP surveys although it should be noted that they were conducted among pregnant women. [46, 74, 88, 89]

The bridging knowledge and practices gap with regard to ZIKA virus infection are vital aspects that must be learned for pregnant women and all members of the community as a whole to increase society's awareness of the seriousness of the disease and how to primarily prevent these risks.

\section{Conclusion}

Based on the results of the present study, it is presumed that the hypothesis of the study is accepted. All women in the study group who attained the program archived better scoring in both knowledge and practices, regarding ZIKA virus, after implementing and attending the program compared to before. There is an observable progression of the total ZIKA infection prevention practice in the satisfactory score and regression in the unsatisfactory one. This is mirrored the effect of the program.

\section{Recommendations}

In light of the findings of this study, the following is recommended:

1. Continued efforts by the health sectors both at the national and local levels are necessary to close knowledge gaps, raise awareness, and promote favorable attitudes toward ZVD.

2. Primary prevention is a key element in reducing potential hazards among high-risk group.

3. Increased the prevention campaigns to improve community awareness of the seriousness of the disease, especially in rural areas

4. Additional research on community awareness, attitudes, and practices around ZIKA virus infection in a variety of locations, especially among groups living in or frequently traveling to endemic regions of ZIKA around the world, would be especially useful in addressing this growing global health issue.

\section{References}

[1] Plourde, A. R., \& Bloch, E. M. (2016). A literature review of Zika virus. Emerging Infectious Diseases, 22(7), 1185-1192. https://doi.org/10.3201/eid2207.151990

[2] Musso, D., Nhan, T., Robin, E., Roche, C., Bierlaire, D., Zisou, K., et al.. (2014). Potential for Zika virus transmission through blood transfusion demonstrated during an outbreak in French Polynesia. Euro Surveill, 19(14).

[3] Messina, J. P., Kraemer, M. U., Brady, O. J., Pigott, D. M., Shearer, F. M., Weiss, D. J., ... Cohn, E. (2016). 
Mapping global environmental suitability for Zika virus. Elife, 5, e15272.

[4] Maurice, J. (2016). The Zika virus public health emergency: 6 months on. Lancet, 388(10043), 449-450.

[5] World Health Organization. (2018). Zika virus and complications: 2016 public health emergency of international concern 2018. Retrieved from http://www.who.int/emergencies/zika-virus/en/

[6] Honein, M. A., Dawson, A. L., Petersen, E. E., Jones, A. M., Lee, E. H., Yazdy, M. M., et al.. (2017). Birth defects among fetuses and infants of us women with evidence of possible Zika virus infection during pregnancy. JAMA, 317(1), 59-68.

[7] World Health Organization. (2017). Situation report on Zika virus, microcephaly and Guillain-Barre syndrome. Retrieved from http://www.who.int/emergencies/zika-virus/situation-report/10-march-2017/en/

[8] Baud, D., Gubler, D. J., Schaub, B., Lanteri, M. C., \& Musso, D. (2017). An update on Zika virus infection. Lancet, 390(10107), 2099-109.

[9] Zanluca, C., et al.. (2015). First report of autochthonous transmission of Zika virus in Brazil. Mem Inst Oswaldo Cruz, 110(4), 569-572.

[10] Petersen, L. R., Jamieson, D. J., Powers, A. M., \& Honein, M. A. (2016). Zika virus. N Engl J Med, 374, 1552-1563.

[11] Besnard, M., Lastere, S., Teissier, A., Cao-Lormeau, V., \& Musso, D. (2014). Evidence of perinatal transmission of Zika virus, French Polynesia. Euro Surveill, 19(13).

[12] Russell, K., Hills, S. L., Oster, A. M., Porse, C. C., Danyluk, G., Cone, M., et al.. (2016). Male-to-female sexual transmission of Zika virus-United States, January-April 2016. Clin Infect Dis, 64(2), 211-213.

[13] World Health Organization. (n.d.). Zika virus factsheet. Retrieved from http://www.who.int/mediacentre/factsheets/zika/en/

[14] Allard, A., Althouse, B. M., Hébert-Dufresne, L., \& Scarpino, S. V. (2017). The risk of sustained sexual transmission of Zika is underestimated. PLoS Pathog, 13, e1006633.

[15] Jamrozik, E., \& Selgelid, J. M. (2018). Ethics, health policy, and Zika: From emergency to global epidemic?. Journal Med Ethics, 44, 343-348.

[16] Vega, W. (2018). Zika Virus: 22 Lessons to Prevent Zika Virus and Save Your Family Zika Virus, Microcephaly Symptoms, Zika Virus Symptoms series. In S. Thulukkanam (Ed.), Assessment of Knowledge on Control and Prevention of Zika Fever Among B.Sc Nursing Students at SRM College of Nursing. International Journal of Pharmaceutical and Clinical Research, 10(3), 79-83.

[17] Nicastri, E., et al.. (2016). Diagnosis of Zika virus infection in pregnant women travelling to or residing in endemic areas. The Lancet Infectious https://doi.org/10.1016/S1473-3099(16)30074-3

[18] Megahed, Kh. (n.d.). Egypt prepared for prevention of Zika outbreak. Retrieved from http://www.amoraview.com/egypt-prepared-for-prevention-of-zika-outbreak/

[19] Abramson, D., \& Piltch-Loeb, R. (2016). Public's Perception of Zika Risk: Awareness, Knowledge, and Receptivity to Public Health Interventions. New York University; New York. U.S.

[20] Harvard, T. H. (2016). Chan School of Public Health Many U.S. families considering pregnancy don't know Zika facts. Retrieved from https://www.hsph.harvard.edu/news/press-releases/zika-virus-awareness-pregnant-women/

[21] Jo, S., Kim, Y., \& Choi, J. (2019). Influencing factors on preventive health behaviours for Zika virus in pregnant women and their partners. Journal Clinical Nursing, 28, 894-901.

[22] Ioos, S., Mallet, H. P., Leparc Goffart, I., Gauthier, V., Cardoso, T., \& Herida, M. (2014). Current Zika virus epidemiology and recent epidemics. Med Mal Infect, 44(7), 302-307.

[23] Rather, I. A., Kumar, S., Bajpai, V. K., Lim, J., \& Park, Y. H. (2017). Prevention and control strategies to counter Zika epidemic. Front Microbiol, 8, 305.

[24] Diniz, D., Medeiros, M., \& Madeiro, A. (2017). Brazilian women avoiding pregnancy during Zika epidemic. BMJ Sexual \& Reproductiove Health, 43, 80.

[25] Musso, D., Roche, C., Robin, E., Nhan, T., Teissier, A., \& Cao-Lormeau, V.-M. (2015). Potential sexual transmission of Zika virus. Emerging Infectious Diseases, 21(2), 359-361. 
[26] Rasmussen, S. A., Jamieson, D. J., Honein, M. A., \& Petersen, L. R. (2016). Zika virus and birth defects-reviewing the evidence for causality. NEJM, 374(20), 1981-1987.

[27] Swaminathan, S., Schlaberg, R., Lewis, J., Hanson, K. E., \& Couturier, M. R. (2016). Fatal Zika virus infection with secondary nonsexual transmission. New England Journal of Medicine, 375(19), 1907-1909.

[28] Korea Centers for Disease Control and Prevention. (2016). Zika Virus Prevention guideline: Korea Centers for Disease Control and Prevention. Korean Centers for Disease Control and Prevention [KCDC]. Retrieved $12 \quad$ January $2017, \quad$ from http://cdc.go.kr/CDC/health/CdcKrHealth0101.jsp?menulds=HOME001-MNU1132-MNU1147-MNU0746MNU2423\& $\mathrm{fid}=7956 \& \mathrm{cid}=68928$

[29] Hassan, H., Zahran, K., Youness, E., \& Nady, F. (2015). Pregnant Women's Awareness, Intention and Compliance regarding Folic Acid Usage for Prevention of Neural Tube Defects According to Health Belief Model in Beni-Suef City. Pyrex Journal of Nursing and Midwifery, 1(3), 13-26.

[30] Farg, D., \& Hassan, H. (2019). Study Hyperemesis Graviderum Requiring Hospital Admission during Pregnancy: Effect of Nursing Implication on Its Progress. American Journal of Nursing Research, 7(3), 328-341. https://doi.org/10.12691/ajnr-7-3-14

[31] Hassan, H., Said, S., \& Hassanine, Sh. (2017). Disparities of prevalence and causes of maternal antenatal anxiety among primigravida pregnant women in Egypt. American Research Journal of Nursing, 3(1), 1-15. https://doi.org/10.9790/1959-051293100

[32] Mostafa, H., Yousef, F., \& Hassan, H. (2018). Health Related Quality of Life Educational Interventions: Effect on Chronic Hepatitis C Patients'. Saudi Journal of Nursing and Health Care, 1(2), 56-67.

[33] Said, S., Hassan, H., \& Sarhan, A. (2018). Effect of an educational intervention on women's knowledge and attitude regarding cervical cancer. American Journal of Nursing Research, 6(2), 59-66. https://doi.org/10.12691/ajnr-6-2-4

[34] Hassan, H., Nady, F., Youns, E., \& Zahran, K. (2016). Call for Change Level of Knowledge, Awareness and Attitude to Follow A High Folate Diet Among Pregnant Women. IOSR Journal of Nursing and Health Science, 5(1), 93-100. https://doi.org/10.9790/1959-051293100

[35] Atwa, A., Hassan, H., \& Ahmed, S. (2019). The impact of a hospital-based awareness program on the knowledge of patients about breast cancer and cancer cervix. International Journal of Studies in Nursing, 4(1), 20-29. https://doi.org/10.20849/ijsn.v4i1

[36] Yakob, L., \& Walker, T. (2016). Zika virus outbreak in Americas: The need for novel mosquito control methods. The Lancet Global Health, 4(3), 148-149.

[37] Zahra, N. (2018). Educational Programme for Pregnant Women About Zika Virus Infection in Benha City. International Journal of Studies in Nursing, 3(2), 65-75.

[38] Korean Nursing Association. (2017). Nurse 10 thousand men, the nursing should havethings. Retrieved from http://webzine.koreanurse

[39] Choi, J., \& Kim, K. (2018). Infection-control knowledge, attitude, practice, and risk perception of occupational exposure to Zika virus among nursing students in Korea: A cross- sectional survey. Journal of Infection and Public Health, 11, 840-844.

[40] Alessa, M., Alzahrani, M., Alshehri, A., Aljrboa, A., et al.. (2020). Knowledge regarding Zika Virus Infection among Healthcare Providers in an Academic Tertiary Care Center in Riyadh, Saudi Arabia: A Cross-Sectional Survey Study. Canadian Journal of Infectious Diseases and Medical Microbiology, 6.

[41] Thulukkanam, S. (2018). Assessment of Knowledge on Control and Prevention of Zika Fever Among B.Sc Nursing Students at SRM College Of Nursing. International Journal of Pharmaceutical and Clinical Research, 10(3), 79-83.

[42] Prue, C., Roth, J., Garcia-Williams, A., Yoos, A., et al.. (2017). Awareness, Beliefs, and Actions Concerning Zika Virus Among Pregnant Women and Community Members -- U.S. Virgin Islands. MMWR, 66(34), 909-913.

[43] Elgendy, A., Hassan, H., Elsaid, F., \& Sherbeny, E. (2018). Nurses' Awareness Regarding Zika Virus in Beni-Suef Governorate. American Research Journal of Public Health, 1(1), 30-42.

[44] Chaw, L., Tuah, N., Wong, J., \& Naing, L. (2018). Knowledge, attitudes and practice survey on Zika virus 
infection among pregnant women in Brunei Darussalam. Asian Pac J Trop Med, 11(11), 638-644.

[45] Samuel, G., DiBartolo-Cordovano, R., Taj, I., Merriam, A., Jean, M., Caroline Torres, L., ... Thakur. K. T. (2018). A survey of the knowledge, attitudes and practices on Zika virus in New York City. BMC Public Health, 18, 98.

[46] Berenson, A., Trinh, H., Hirth, J., Guo, F., Fuchs, E., \& Weaver, S. (2017). Knowledge and Prevention Practices among U.S. Pregnant Immigrants from Zika Virus Outbreak Areas Abbey. Am J Trop Med Hyg, 97(1), 155-162.

[47] Raman, A., Dubaut, J., Burks, H., \& Quaas, A. (2017). Knowledge, attitudes and practices regarding zikavirys in patients presenting for infertility teatment and health care professionals. ASRM Abstracts, $108(3)$.

[48] Harapan, H., Aletta, A., Anwar, S., Setiawan, A., Maulana, R., Wahyuniati, N., et al.. (2017). HCWs' knowledge towards Zika virus infection in Indonesia: a survey in Aceh. Asian Pac J Trop Med, 10(2), 189-194.

[49] Moore, K. (2016). Assessing nurse practitioner knowledge of Zika virus. Journal for Nurse Practitioners, 12(10), 697-703.

[50] Moore, K. S. (2016). Assessing Nurse Practitioner Knowledge of Zika Virus. The Journal for Nurse Practitioners, 703, e4.

[51] Gupta, N., Randhawa, R., Thakar, S., Bansal, M., Gupta, P., \& Arora, V. (2016). Knowledge regarding Zika virus infection among dental practitioners of tricity area (Chandigarh, Panchkula and Mohali), India. Nigerian Postgraduate Medical Journal, 23(1), 33-37.

[52] Haddow, A. D. (2012). Genetic Characterization of Zika Virus Strains: Geographic Expansion of the Asian Lineage.

[53] Shartzer, A., Johnston, E., Courtot, B., \& Kenney, G. (2016). Women of reproductive age lack knowledge of zika virus transmission and effects. Urban Institute.

[54] Cheema, S., Maisonneuve, P., Weber, I., Fernandez-Luque, L., Abraham, A., Alrouh, H., \& Mamtani, R. (2017). Knowledge and perceptions about Zika virus in a Middle East country. BMC Infectious Disease, 17(1), 524. https://doi.org/doi.org/10.1186/s12879-017-2603-6

[55] Harapan, H., Rajamoorthy, Y., Utomo, P., et al.. (2019). Knowledge and attitude towards pregnancy-related issues of Zika virus infection among general practitioners in Indonesia. BMC Infectious Diseases, 19(1), 693.

[56] Harapan, H., Mudatsir, M., Indah, R., et al.. (2019). Knowledge towards Zika among medical students, interns and general practitioners in Indonesia: a cross-sectional study in Aceh. Clinical Epidemiology and Global Health, 7(4), 542-545.

[57] Ricamonte, B., Jover, C., Oducado, R., Ngitngit, E., Hiponia, A., \& Macables, G. (2018). Knowledge and Attitude toward Zika Virus Disease among Pregnant Women in Iloilo City, Philippines. Public Health Research, 8(5), 115-120.

[58] Khan, M., Ahmad, A., Arief, M., Saleem, F., Hassali, M., \& Bhagavathula, A. (2016). Public knowledge and attitudes towards zika virus and its prevention in Malaysia. The Journal of the International Society for Pharmacoeconomics and Outcomes Research, 19(7), A423-A424.

[59] Arief, M., Hassali, M., Saleem, F., Khan, M., Ahmad, A., Bhagavathulha, A., \& Jamshed, S. Q. (2016). A cross-sectional survey on the knowledge and attitudes towards zika virus and its prevention among residents of Selangor, Malaysia. Journal of Pharmacy Practice and Community Medicine, 3(2), 81-89.

[60] Iqbal, M., Tahnir, M., Lokanayagi, S., Rahul, R., Chong, L., Kho, Z., \& Kumar, P. (2016). Knowledge, attitude and perception of zika virus among healthcare students of medicine, pharmacy and dentistry of AIMST University. Value in Health, 19(7), A484.

[61] Singh, M., Singh, K., Puri, M., Anandani, C., Singh, H., et al.. (2017). Knowledge and perception towards zika outbreak in a dental institute. Dentistry, 7(3), 420. https://doi.org/10.4172/2161-1122.1000420

[62] Hassan, H., \& Nasr, E. (2017). Improving nurses' knowledge and skills regarding tocolytics for inhibiting preterm labor. Clinical Nursing Studies, 5(1), 1-12. https://doi.org/10.5430/cns.v5n1p1

[63] Mohamed, W., \& Hassan, H. (2020). Effect of instructional supportive guideline for improving women's 
awareness towards endometriosis. American Journal of Nursing Research, 8(1), 38-47. https://doi.org/10.12691/ajnr-8-1-5

[64] Hassan, H., Malk, R., Abdelhamed, A., \& Genedy, A. (2020). Infection Control Knowledge and Practices: Program Management in Labor Units According to Standard Infection Control Precautions in Northern Upper Egypt. American Journal of Nursing Research, 8(4), 412-425. https://doi.org/10.12691/ajnr-8-4-1

[65] Sheha, E., Hassan, H., Genedy, A., \& Hassanine, Sh. (2020). Effect of educational program on mother's knowledge and practice regarding Hepatitis C Virus in rural areas. American Journal of Nursing Research, 8(3), 303-310. https://doi.org/10.12691/ajnr-8-3-1

[66] Hassan, H. (2019). Integrative Nursing Science in Women's Pre-conceptional Wellness. International Journal of Health and Biological Sciences, 2(1), 17-18.

[67] Hassan, H., Mohamady, Sh., \& Abd El-Gawad, N. (2017). Protocol for improving nursing performance towards placental examination at labor units. Clinical Nursing Studies, 5(2), 1-11. https://doi.org/10.5430/cns.v5n2p1

[68] Gamel, W., Genedy, A., \& Hassan, H. (2020). Impact of puerperal sepsis self-care nursing guideline on women's knowledge and practices. American Journal of Nursing Research, 8(2), 132-141. https://doi.org/10.12691/ajnr-8-2-1

[69] Mohamed, W., \& Hassan, H. (2019). Educational program to enhance pregnant women's knowledge about dental care and periodontitis outcomes. ARC Journal of Nursing and Healthcare, 5(3), 23-33. https://doi.org/10.20431/2455-4324.0503004

[70] Masters, K. (2013). Edgar Dale's Pyramid of Learning in medical education: A literature review. Medical Teacher, 35(11), e1584-e1593. https://doi.org/10.3109/0142159X.2013.800636

[71] Aung, M., Oo, W., Lynn, K., \& Mya, K. (2015). Knowledge and perception towards Ebola virus disease among nursing students in the University of Nursing, Yangon. Myanmar Med Journal, 57(3), 8-14.

[72] Gupta, N., Mehta, N., Gupta, P., Arora, V., \& Setia, P. (2015). Knowledge regarding Ebola hemorrhagic fever among private dental practitioners in Tricity, India: A cross-sectional questionnaire study. Niger Med Journal, 56, 138-142.

[73] Huang, Y., Xu, S., Wang, L., Zhao, Y., Liu, H., Yao, D., \& Wu, Q. (2017). Knowledge, attitudes, and practices regarding Zika: Paper-and Internet-based survey in Zhejiang, China. JMIR Public Health and Surveillance, 3(4), e81. https://doi.org/10.2196/publichealth.7663

[74] Taís, P., \& David, C. (2017). Pregnant Awareness about Zika Virus infection during Pregnancy. Brazilian Journal of Medicine and Human Health, 5(4), 1085-1087.

[75] Heitzinger, K., Thoroughman, D., \& Porter, K. (2018). Knowledge, attitudes, and practices of women of childbearing age testing negative for Zika virus in Kentucky. Preventive Medicine Reports, 10, 20-23.

[76] Brissett, D., Tuholske, C., Allen, I., et al.. (2018). Zika virus: Knowledge assessment of residents and health-care providers in Roat an following an outbreak. Am J Trop Med Hyg, 99, 211-215.

[77] Quinn, C., Poirot, E., Sanders, K. A., et al.. (2018). Variations in healthcare provider use of public health and other information sources by provider type and practice setting during New York City's response to the emerging threat of Zika virus disease. Health Secur, 16, 252-261.

[78] Sharma, S., Tyagi, A., Ramachandra, S., Bhuyan, L., Dash, K., \& Raghuvanshi, M. (2018). Knowledge, attitudes, and practices among health-care providers regarding Zika virus infection. J Int Soc Prevent Communit Dent, 8, 41-47.

[79] Hajikazemi, E., Oskouie, F., Mohseny, S., \& Nikpour, S. (2008). The Relationship between Knowledge, Attitude, and Practice of Pregnant Women about Oral and Dental Care. European Journal of Scientific Research, 24, 556-562.

[80] Yap, J., Lee, V., Yau, T., \& Tor, P. (2010). Knowledge, attitude and practices Toward Pandemic Influenza among cases, close contacts and health care workers in Tropical Singapore: across-Sectional Survey. BMC Public Health, 10, 442. https://doi.org/10.1186/1471-2458-10-442

[81] Lobo, D., Sams, L., \& Fernandez, S. (2019). Correlation between health professionals' knowledge, attitude and practice about infection control measures. J Med Allied Sci, 9(1), 26-31.

[82] Munivenkatappa, S., \& Govindaraj, S. (2019). A study evaluating knowledge of and attitude towards 
hepatitis B among pregnant women at a teaching hospital in Nellore, India. Int J Reprod Contracept Obstet Gynecol, 8(8), 3183-3188.

[83] Kaushal, G., Doke, P., Shah, A., \& Verma, V. (2015). An Analysis of Knowledge, Attitude and Practices regarding Standard Precautions of Infection Control and Impact of Knowledge and Attitude of ICU Nurses on Self-reported Practices of Infection Control. International Journal of Research Foundation of Hospital \& Healthcare Administration, 3(2), 79-85.

[84] Sheha, E., Soultan, A., Malk, R., \& Elsherbeny, E. (2020). Effect of a Planned Health Teaching on Improving Knowledge and Competence of Home Care Practice of Post Stroke Patient Among Caregivers' Achievement. International Journal of Studies in Nursing, 5(2), 51-69.

[85] Iliyasu, G., Dayyab, F., Habib, Z., Tiamiyu, A., Abubakar, S., Mijinyawa, M., \& Habib, A. (2016). Knowledge and practices of infection control among healthcare workers in a Tertiary Referral Center in North-Western Nigeria. Ann Afr Med, 15(1), 34-40.

[86] Argüelles-Nava, V., Alvarez-Bañuelos, M., Córdoba-Suárez, D., Sampieri, C., Ortiz-León, M., Riande-Juárez G., \& Montero, H. (2018). Knowledge, Attitudes, and Practices about Zika among a University Community Located in an Endemic Zone in Mexico. Int J Environ Res Public Health, 15(11), 2548 .

[87] Nelson, E., Luetke, M., McKinney, C., \& Omodior, O. (2018). Knowledge of the Sexual Transmission of Zika Virus and Preventive Practices Against Zika Virus Among U.S. Travelers. Journal of Community Health. https://doi.org/10.1007/s10900-018-0594-x.

[88] Squiers, L., Herrington, J., Kelly, B., et al.. (2018). Zika virus prevention: U.S. travelers' knowledge, risk perceptions, and behavioral intentions-A national survey. The American Journal of Tropical Medicine and Hygiene, 98(6), 1837-1847.

[89] Whittemore, K., Tate, A., Illescas, A., et al.. (2017). Zika virus knowledge among pregnant women who were in areas with active transmission. Emerging Infectious Diseases, 23(1), 164-166.

\section{Copyrights}

Copyright for this article is retained by the author(s), with first publication rights granted to the journal.

This is an open-access article distributed under the terms and conditions of the Creative Commons Attribution license (http://creativecommons.org/licenses/by/4.0/). 